\title{
Determination of the moisture content of white and yellow corn from ohaji in imo state of nigeria using the dry-weight technique
}

Offurum, J. C. ${ }^{\mathrm{a} *}$; Morgan, C.M. ${ }^{\mathrm{a}}$

${ }^{a}$ Department of Chemical Engineering, Imo State Polytechnic, Umuagwo-Ohaji

*E-mail of the corresponding author: jullyengine@yahoo.com

\begin{abstract}
The water content determination of two maize species (Yellow corn- and White corn-), located at Ohaji in Imo State of Nigeria was considered in this study. This was motivated by the regular reported cases of the seed postharvest spoilages. Modified High Constant Temperature Oven method, as prescribed by the International Seed Testing Association was employed, at a temperature of $1320 C$. The procedure for each sampling was replicated accordingly, and the mean value was identified as the actual result. The moisture content for Sample A (white corn) was found to be $31.6 \%$, while that of Sample B (yellow corn) was found to be $21.5 \%$, which shows that the yellow corn would always have longer storage value than the white corn. As any change in the seed moisture has a way of affecting its storage life, it is advisable not to store the white corn longer than it could be applied to the yellow corn
\end{abstract}

Keywords: Determination, Moisture Content, White Corn, Yellow Corn, Dryweight Basis. 


\section{Introduction}

Moisture content of a seed can be described as the percentage quantity of water in the seed at a given time (1). The moisture content can be expressed on either weight basis (percentage of the weight of the fresh seed) or on dry-weight basis (percentage of the dryweight of the seed). The seed moisture content is among the factors that determine whether or not the seed can be stored safely without loss of germination and vigour (2). In most cases, higher moisture content encourages higher heat content of the seed, which regularly prepares the seed for bacterial growth. As seeds of a given crop would usually have high moisture content at maturity, they become (more or less) naturally unsafe for storage without reducing their inherent percentage moisture content through applicable drying technique. The essence of drying is to reduce the excess moisture of the seeds that has the capacity of exposing them to microbial contamination and spoilage (3).

When a seed/grain dries, it releases its moisture into the drying air, and consequently, loses weight upon which the moisture content assessment depends. The range of systems available for drying seeds varies, from thin-layer under the sun (or simple maize crib), through oven-drying, to extensive mechanized systems (such as use of continuous-flow dryers). But the choice of any of these systems depends on a number of factors, such as rate of harvest, volume of seeds (to be dried), available storage facilities, as well as flexibility $(4,5)$. As a very important cereal plant that is widely grown in Nigeria for both human food and livestock feed, maize is used in the industrial production of alcohol, starch and oil (6). It is economically not important to store maize seeds that are above $23 \%$ moisture content in a grain bin, as the kernels may freeze together and, subsequently, deform or stick together (7). Post-harvest management of maize seeds demands critical attention towards providing a good aerated (cool) condition for keeping the corn, as wet corn will deteriorate very easily. The use of maximum (but optimum) drying temperature during corn drying encourages drying efficiency and lowers the total required drying energy. On the other hand, decreasing the drying temperature in the lower portion (especially for a multistage dryer) could reduce the susceptibility to heat damage.

However, as much as the seeds could be preserved when dried (at appropriate drying conditions), they could also be damaged when dried too rapidly (over-dried), and any change in the moisture content of the seed affects the storage life of the seed. These, thus, necessitated the present study, which centers on the moisture content determination of two maize species- Sorghum and Var. Rugosa (white and yellow corns) from Ohaji, in Imo State of Nigeria. 


\section{Materials and Methods}

The two maize samples used in this study were collected from a Late-planting farm (upon maturity) at Awarra-Ohaji, which is located at the Western part of Owerri, the Imo State capital in Nigeria. The method of moisture content determination adopted in this work is the modified high-constant temperature oven method, prescribed by the International Seed Testing Association (ISTA) (8)

\subsection{Pre-drying}

Exactly $1.0000 \mathrm{~g}$ of each of the seed samples was weighed into a dish using analytical weighing balance, to obtain the weight, $W_{l}$. The dish (of seed) was left in a warm dry place over-night. After 24hours, the sample was taken and re-weighed to obtain the weight, $W_{2}$. The percentage moisture content for the pre-drying stage, $S_{l}$ was evaluated using Eq. 1.

$S_{1}=\frac{W_{1}-W_{2}}{W_{1}} X \frac{100}{1}$

Where $\mathrm{W}_{1}=$ Weight of dish and fresh seed

$\mathrm{W}_{2}=$ Weight of dish and pre-dried seed

\subsection{Grinding}

Each of the pre-dried seed samples was grinded to about $1 \mathrm{~mm}$ size distribution, and then placed in a clean dry dish separately

\subsection{Drying}

The ground form of each of samples was weighed into a clean dry dish using analytical weighing balance, to obtain the initial weight, $W_{3}$. The dish was the carefully placed in a thermostat oven set at $132^{\circ} \mathrm{C}$. When the oven temperature reached the set point, the switched went off automatically, and the oven operation was maintained for a holding time 4hours (at that temperature). At the elapse of the time, the dish was removed and placed inside a (covered) desicator, to cool for 40munites (at room temperature). The sample was then removed and re-weighed, to obtain the final weight, $W_{4}$. The moisture content of the normal drying, $\mathrm{S}_{2}$ was evaluated using Eq. 2.

$S_{2}=\frac{W_{3}-W_{4}}{W_{a}} X \frac{100}{1}$

Where $\mathrm{W}_{3}=$ Weight of dish and ground seed

$\mathrm{W}_{4}=$ Weight of dish and dried seed.

The final moisture content, $M$ was obtained using Eq. 3 
Determination of the moisture content of white and yellow corn from ohaji in imo state of nigeria using the dryweight technique

$M(\%)=\left(S_{1}+S_{2}\right)-\frac{S_{1} X S_{2}}{100}$

Where $S_{1}=$ Percentage moisture content from Pre-drying

$\mathrm{S}_{2}=$ Percentage moisture content from Drying

This procedure was, however, replicated for each of the seed samples (giving rise to $R_{l}$ and $R_{2}$ data for each Sample), and the average moisture content, $M_{a v g}$.was evaluated using Eq. 4 .

$M_{\text {avg }}=\frac{S_{1}+S_{2}}{2}$

\section{Result and Discussion}

The results of the dry-weight measurements for Samples A and $\mathbf{B}$ are presented in Tables 1 and 2 respectively, while those of the moisture contents are presented in Table 3.

Table 1: Dry-weight Analysis of Sample A (White Corn)

\begin{tabular}{|c|c|c|c|}
\hline Dish Number & Weight of Dish, $g$ & $\begin{array}{l}\text { Weight of (Dish and } \\
\text { Fresh Feed), } g\end{array}$ & $\begin{array}{c}\text { Weight of (Dish and } \\
\text { Dry Feed), } g\end{array}$ \\
\hline
\end{tabular}

Pre-drying Stage

\begin{tabular}{lccc}
\hline 1 & 20.3500 & 34.3313 & 32.4419 \\
2 & 20.4424 & 34.4224 & 33.0248 \\
\hline \multirow{3}{*}{ Drying Stage } \\
\hline 3 & 10.8611 & 14.5201 & 13.7928 \\
4 & 10.9130 & 14.6046 & 14.3521 \\
\hline
\end{tabular}

Table 2: Dry-weight Analysis of Sample B (Yellow Corn)

\begin{tabular}{lccc}
\hline Dish Number & Weight of Dish, $g$ & $\begin{array}{c}\text { Weight of (Dish and } \\
\text { Fresh Feed), } g\end{array}$ & $\begin{array}{c}\text { Weight of (Dish and } \\
\text { Dry Feed), } g\end{array}$ \\
\hline \multicolumn{3}{c}{ Pre-drying Stage } \\
\hline 2 & 22.0025 & 36.6240 & 33.9925 \\
& 22.9034 & 36.7071 & 35.0059
\end{tabular}

\begin{tabular}{lccc}
\hline \multicolumn{3}{c}{ Drying Stage } \\
\hline 3 & 11.1424 & 15.5036 & 15.3016 \\
4 & 11.8013 & 16.0411 & 15.8512 \\
\hline
\end{tabular}


Table 3: Moisture Content Analysis of the Samples

\begin{tabular}{|c|c|c|c|c|c|c|}
\hline \multirow{2}{*}{$\begin{array}{l}\text { Moisture } \\
\text { Content (\%) }\end{array}$} & \multicolumn{3}{|c|}{$\mathbf{A}$} & \multicolumn{3}{|c|}{ B } \\
\hline & $S_{1}(\%)$ & $S_{2}(\%)$ & M (\%) & $S_{1}(\%)$ & $S_{2}(\%)$ & M (\%) \\
\hline $\mathbf{R}_{1}$ & 13.5 & 19.9 & 30.7 & 18.0 & 5.5 & 22.5 \\
\hline $\mathbf{R}_{2}$ & 31.5 & 1.4 & 32.5 & 12.3 & 9.4 & 20.5 \\
\hline Average "M" & \multicolumn{2}{|c|}{$M_{\text {avg. }}(\%)$} & 31.6 & \multicolumn{2}{|c|}{$M_{\text {avg. }}(\%)$} & 21.5 \\
\hline
\end{tabular}

The results of the moisture content $(\mathrm{M})$, in Table 3, show that there is no significant difference between the replications (R1 and R2). In other words, the differences between the R-values, for both samples, fall within the limits of +2 , indicating absolute homogeneity and acceptability of the data $(9,10,11)$. The moisture content of Sample A $(31.7 \%)$ was observed to be greater than $23 \%$, and as such should not be stored in poly bags or grain bins, as this may cause the kernels to freeze and bind together, unlike Sample B that can be reliably stored in a grain bin (7). Alternatively, storage of shelled corns of higher moisture contents $(>25 \%)$ should be in silos or silo bags (7)

\section{Conclusions}

The white corn has higher moisture content than the yellow corn. During post-harvest management of the grains, white corns should be stored in silos or silo bags, while the yellow corns could be stored in poly bags or grain bins. Generally, the seeds of the white maize should not be stored for longer periods as could be applicable to those of the yellow maize (under natural drying conditions), because of the high moisture content of the former; this will create enabling room for optimum exploitation of their storage values

\section{References}

[1] Copland, L.O. Seed Drying; Burgress Publishing Company: Minnesota, 1976; 257 272.

[2] Siddique, A.B. and Wright, D. Effects of Different Drying Time and Temperature on Moisture Percentage and Seed Quality (Viability and Vigour) of Pea Seeds (pisum sativum L.); Asian Journal of Plant Sciences, 2003; 2(1), 978-982.

[3] McLean, K.A. Drying and Storing Combinable Crops; Farming Press: U.K., 1989; 224-238.

[4] Food and Agricultural Organization, FAO. Processing and Storage of Food Grains by Rural Families; Agricultural Services Bulletin, 1983; (53). 
Determination of the moisture content of white and yellow corn from ohaji in imo state of nigeria using the dryweight technique

[5] Kernick, M.D. Drying and Cleaning; Food and Agricultural Organization of the United Nations: Rome, 1961; 21-99.

[6] Kling, J.G. and Edmeades, G. Morphology and Growth of Maize; Research Guide: Training Programme; International Institute of Tropical Agriculture, IITA: IbadanNigeria, 1997; (9), 3-6.

[7] Hellevang, K. Corn Drying and Storage Tips; NDSU Extension Services: New York, 2011; 1-9.

[8] International Seed Testing Association, ISTA. International Rules for Seed Testing; Seed Science Technology: 1976; 4: 1-49.

[9] Waston, S.A. Corn Chemistry and Technology; Association of Cereal Chemists: U.S.A., 1987.

[10] Dorsey-Redding, C., Hururgh Jr, C.R., Johnson, L.A. and Fox, S.R. Adjustment of Maize Quality Data for Moisture Content; Association of Cereal Chemists: U.S.A., 1990; 67(3); 292-295.

[11] Rural Structures Unit. The Improved Maize Crib: a Guide to Small Farm Grain Storage; Ministry of Agriculture: Nakuru, 1984; (1).

\section{Appendix 1}

$\mathrm{R}_{1}$

$$
\begin{aligned}
& \mathbf{S}_{\mathbf{1}}=\frac{34.3313-32.4419}{34.3313-20.3500} \times \frac{100}{1}=\frac{1.8894}{13.9813} \times \frac{100}{1}=13.5 \% \\
& \mathbf{S}_{2}=\frac{14.5201-13.7928}{14.5201-10.8611} \times \frac{100}{1}=\frac{0.7273}{3.6590} \times \frac{100}{1}=19.9 \% \\
& \mathbf{M}=(13.5+19.9)-\frac{(13.5 \times 19.9)}{100}=33.4-2.67=30.7 \%
\end{aligned}
$$

$\mathrm{R}_{2}$

$\mathbf{S}_{\mathbf{1}}=\frac{34.4224-30.0248}{34.4224-20.4424} \times \frac{100}{1}=\frac{4.3976}{13.9800} \times \frac{100}{1}=31.5 \%$

$\mathbf{S}_{2}=\frac{14.6046-14.5521}{14.6046-10.9130} \times \frac{100}{1}=\frac{0.0525}{3.6916} \times \frac{100}{1}=1.4 \%$

$\mathbf{M}=(31.5+1.4)-\frac{(31.5 \times 1.4)}{100} \quad=32.9-0.441=32.5 \%$

Mavg. $=\frac{30.7+32.5}{2}=\mathbf{3 1 . 6 \%}$ 


\section{A. Moisture Content Computation for Sample B}

$\left(\mathrm{R}_{1}\right)$

$$
\begin{aligned}
& \mathbf{S}_{1}=\frac{36.6240-33.9925}{36.6240-22.0025} \times \frac{100}{1}=\frac{2.6315}{14.6215} \times \frac{100}{1}=18.0 \% \\
& \mathbf{S}_{2}=\frac{15.5036-15.3016}{15.5036-11.8013} \times \frac{100}{1}=\frac{0.2020}{3.7023} \times \frac{100}{1}=5.5 \% \\
& \mathbf{M}=(18.0+5.5)-\frac{(18.0 \times 5.5)}{100}=23.5-0.99=22.5 \%
\end{aligned}
$$

$\left(\mathrm{R}_{2}\right)$

$$
\begin{aligned}
& \mathbf{S}_{1}=\frac{36.7071-35.0059}{36.7081-22.9034} \times \frac{100}{1}=\frac{1.7012}{13.8037} \times \frac{100}{1}=12.3 \% \\
& \mathbf{S}_{\mathbf{2}}=\frac{16.0411-15.8512}{16.0411-11.1424} \times \frac{100}{1}=\frac{0.4599}{4.8987} \times \frac{100}{1}=9.4 \% \\
& \mathbf{M}=(12.3+9.4)-\frac{(12.3 \times 9.4)}{100 \mathrm{~s}}=21.7-1.2=20.5 \%
\end{aligned}
$$

Mavg. $=\frac{22.5+20.5}{2}=21.5 \%$ 